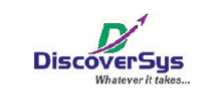

Published by DiscoverSys

\section{Analysis of the Birth Insurance Program (Jampersal) utilization in Bangli District, Bali, Indonesia}

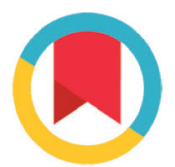

CrossMark

\author{
Ni Made Ayu Kemala Dewi, ${ }^{1 *}$ Yuli Kurniati, ${ }^{2}$ Pande Putu Januraga ${ }^{2}$
}

\begin{abstract}
Background and purpose: The Birth Insurance Program or called Jaminan Persalinan (Jampersal) aims to reduce maternal and newborn deaths. Bangli is one of the districts in Indonesia with low utilisation of Jampersal program. The study aims to explore factors associated with the low utilization and uptake of Jampersal Program in Bangli District.

Methods: This was a qualitative study conducted between AprilMay 2019. The study involved 24 informants who were selected purposively. The informants were 18 pregnant women, two community leaders, three health workers and one Bangli Health Office's staff. Data were collected through in-depth interviews which explore factors associated to utilisation of Jampersal using PRECEDE-PROCEED Framework. Data were analyzed by thematic analysis.

Results: We found that informants who used Jampersal had

sufficient knowledge about Jampersal, were exposed to the program informed by health workers and community leaders, and were supported by their families. Whereas, those who yet to utilize Jampersal had a poor understanding on Jampersal service mechanisms, lack of spousal support in preparing Jampersal requirements and private midwives had not signed the Jampersal MoU.

Conclusion: Low utilisation of Jampersal Program in Bangli District partially influenced by low understanding of the program and in-optimal involvement of midwifery networks. The local health office should further expand cooperation with the private midwife network for optimum utilization of Jampersal, elucidation of the Jampersal technical guidelines to health workers, as well as technical support for participants in completing required documents.
\end{abstract}

Keywords: Jampersal, utilization analysis, maternal and child health, Bangli District

Cite this Article: Dewi, N.M.A.K., Kurniati, Y., Januraga, P.P.2020. Analysis of the Birth Insurance Program (Jampersal) utilization in Bangli District, Bali, Indonesia. Public Health and Preventive Medicine Archive 8(1): 47-52. D01: 10.15562/phpma.v8i1.244

'Bali Provincial Health Office ${ }^{2}$ Department of Public Health and Preventive Medicine, Faculty of Medicine, Udayana University

*Correspondence to: Ni Made Ayu Kemala Dewi; Bali Provincial Health Office; kemalaromfis@gmail.com

\section{INTRODUCTION}

In the last five years, the health status of mothers and babies in Indonesia has shown an improvement. Coverage of antenatal services, childbirth assisted by health workers, family planning and infant visits also increased. These facts indicate improvement on the access to maternal and child health $(\mathrm{MCH})$ services. Despite these improvements in the $\mathrm{MCH}$ status and increased community access to $\mathrm{MCH}$ services, there are disparities between provinces, socio-economic and educational gradients, and between urban and rural area. Hence, the reduction in maternal mortality rate (MMR) and infant mortality rate (IMR) in Indonesia remain far from the Sustainable Development Goals (SDGs) target. ${ }^{1}$

To accelerate the reduction of MMR and IMR, in 2011, the Indonesia Ministry of Health issued a policy known as the Birth Insurance Program which is in Indonesia called Jaminan Persalinan (Jampersal). The program covers provision of referral transportation costs, maternity waiting home (MWH) and delivery assistance services for underprivileged and disadvantaged pregnant mothers who do not have a health insurance card.

Participants in the Jampersal Program are pregnant women, postpartum mothers (up to 42 days after delivery) and newborns aged zero to twenty-eight days (0-28 days) who do not yet have health financing guarantees. The Jampersal fund is used for transportation costs for referrals to health service facilities, the provision of $\mathrm{MWH}$ and delivery assistance services for poor pregnant women who do not have a national health insurance which called Jaminan Kesehatan Nasional (JKN) or a health insurance card called Kartu Indonesia Sehat (KIS) or other funding sources. This is intended to increase access and prevent delays in the care of pregnant women, delivering mothers, postpartum mothers and newborns, especially in the areas with difficult access to health facilities. ${ }^{2}$ Pregnant women who are not poor, either they have or do not have JKN can utilize Jampersal funds for certain activities, 
including referral transportation, utilization of MWH and Congenital Hypothyroid Screening Program or Skrining Hipotiroid Kongenital (SHK). ${ }^{3}$

Some regions in Indonesia have low Jampersal funding utilisation. ${ }^{2}$ One of the regions with very low absorption is Bangli District in Bali. The Jampersal funding ceiling is IDR 843,997,000 however only IDR $98,397,500$ or around $11.66 \%$ has been absorbed. ${ }^{4}$ Studies related to Jampersal reported several constraints in the utilization of the funds were the reporting activities aspects, perceptions of prospective users which related to awareness of the program and service needs, ${ }^{5,6}$ but these predictors have not been systematically mapped. This study aims to analyze the utilization of the Jampersal Program based on the predisposing, reinforcing and enabling factors in mothers who have used and not used the Jampersal Program in Bangli District in 2018 .

\section{METHODS}

This study uses a qualitative design that aims to explore and seek empirical explanations about the use of the Jampersal Program in Bangli District in 2018. The theoretical framework used for data collection and analysis was the PRECEDEPROCEED Framework by Lawrence W. Green and Kreuter. ${ }^{7}$ This model is applied to analyze the community behavior of accessing health services based on the predisposing, enabling and reinforcing factors.

The study was conducted in Bangli District by in-depth interviews with respondents from the working area of Kintamani III Public Health Centre (PHC), which had the highest utilization of Jampersal and Tembuku I PHC, which had the

\section{Table 1. Informant criteria}

\begin{tabular}{|c|c|c|}
\hline & Informant & Number \\
\hline \multirow[t]{4}{*}{1.} & Informants who have used Jampersal: & \\
\hline & $\begin{array}{l}\text { - Maternity/pregnant/childbirth/post-partum mothers/ } \\
\text { mothers of high risk newborns referred }\end{array}$ & 3 \\
\hline & - $\quad$ normal maternity mothers & 3 \\
\hline & - $\quad$ pregnant/childbirth/ post-partum women who use MWH & 3 \\
\hline \multicolumn{3}{|c|}{ 2. Informants who do not use Jampersal: } \\
\hline & $\begin{array}{l}\text { Maternity/pregnant/childbirth/post-partum mothers/ } \\
\text { mothers of high risk newborns referred }\end{array}$ & 3 \\
\hline & - $\quad$ normal maternity mothers & 3 \\
\hline & $\begin{array}{l}\text { - pregnant/childbirth/post-partum women who use the pre- } \\
\text { delivery rooms }\end{array}$ & 3 \\
\hline 3. & Community leaders & 2 \\
\hline & Health workers: & \\
\hline & - $\quad$ PHC midwife & 2 \\
\hline & - $\quad$ Hospital midwife & 1 \\
\hline & Bangli District Health Office & 1 \\
\hline \multicolumn{2}{|c|}{ Total } & 24 \\
\hline
\end{tabular}

lowest utilization of Jampersal. Source triangulation was also carried out on health workers from the Kintamani I PHC, Bangli District Health Office and Bangli District Hospital. Data collection was carried out in April-May 2019. In total, there were 24 respondents interviewed, whom divided into four groups as shown in Table 1.

The data were analysed using thematic analysis based on the procedure described by Braun and Clarke. ${ }^{8}$ All informants have signed an informed consent and we have obtained an Ethical Clearance from the Ethics Committee of the Faculty of Medicine, Udayana University/Sanglah Hospital, Denpasar, No. 679/UN14.2.2.VII.14/LP/2019, on 22 March 2019.

\section{RESULTS}

The results of the analysis show several differences in predisposing, enabling and reinforcing factors among those who have used and have not used Jampersal. Health worker responses also reinforced findings on factors related to the use of Jampersal in Bangli District. The following are the groups of factors that were identified in this study.

\section{Predisposing factors}

People who use Jampersal services received information about the benefits of Jampersal based on information directly from health workers. Even though they reported incomplete understanding of the program, they were able to understand their rights and the necessary documents required to participate in the program.

"......Jampersal is the birth assistance program. Something like that hehehe: from the head of village wife...just like that, for those whose expected birth date is near and they don't have the KIS, they can use Jampersal..., that's what I heard... what the midwife told me...just helps cover the costs..,"(J.Salin.01)

Another factor that affects the perception of the ease of the Jampersal program is the experience of neighbors who have used it before. The informant's neighbor explained that Jampersal helped the poor/ underprivileged, praised the provision of $\mathrm{MWH}$ and hoped that the Jampersal Program would continue.

"...If you want to use the Jampersal you have to let them know so that they can sort out the administration....it is actually quite easy... someone I know did it....they said that it was easy, made things comfortable, quickly assisted by staff....they said it is a good idea to go with the program..."(J.Salin.01)

Nevertheless, there are informants who were aware about Jampersal but have not utilized it 
because of the lack of support from their husbands in preparing the Jampersal requirements, mainly because they felt that preparing administrative requirements was difficult, time consuming and also husbands were busy working.

"There was an issue....it seemed all a bit complicated....had to go to a number of government offices....my husband wasn't interested....such much trouble better off just paying.... that is what my husband said" (TJ.Salin.01)

Another issue that inhibits the use of Jampersal is preference related to the place of delivery. There were informants who had been informed about the Jampersal Program but decided to continue giving birth in other midwifery clinics for their own reasons, including their personal preference of the midwife and negative experiences with health services at the hospital. Other reason was the hospital location, which was far from home, while Jampersal Program in Bangli District yet to cover birthing assistance at midwifery practices.

"I wanted to give birth with my midwife...I am still a bit scared to go to the hospital...so I went to the midwife..... I thought I didn't need to process the National Health Insurance membership because my husband already had it. We thought we could use it for me too, but it turns out no."(TJ. Salin.03)

Finally, what is also key is the decision-making mechanism in the family. There are informants who do not even know about the free Jampersal Program, its purpose and benefits, and this is because the first recipient of the information is the husband, and the husband decides to use (or not use) the service without consulting his wife.

"My husband said (supported by Jampersal)... no, I don't know I said don't know (I don't know the purpose of Jampersal)....from village leader's wife (my husband learnt about jampersal)...." (J.Salin.02)

\section{Enabling factors}

For enabling factors, there are three factors related to the use of Jampersal, namely well-promoted policies, supervision by teams and providers who want to facilitate service administration. The implementation of the Jampersal Program in Bangli District has been regulated in the Decree of Bangli Regent No. 447/77/2018 regarding utilization of the 2018 fiscal year insurance fund. In this decree are listed all provisions contained in the Jampersal Program Technical Guidelines including the administrative provisions. The program introduction meetings were carried out in an integrated manner with other program promotion, especially those related to health insurance and

\section{$\mathrm{MCH}$ referrals.}

There was a change in the Jampersal system where the Jampersal MoU is only signed with the PHC, Government Hospital and Private Hospital; while eliminates the private midwife practice from the list, even though many people choose midwife assisted delivery rather than the hospital or clinic.

Another enabling factor is the supervisory teams who has been working optimally. According to informants, one of the Jampersal service utilization which need more supervision is the utilization of MWH. Based on informants who have used MWH, they only have to sign administration. The health office informant explained that MWH service claim will be paid only if there is provision of meals twice a day, but if the meals were not provided, the service coverage cannot be claimed. Therefore, the supervision should be improved and integrated with the JKN program.

What was then quite influential was the willingness of service providers to facilitate the administration process of Jampersal. In fact, this was stated in the Jampersal MoU with health facilities wherein those who did not have the correct supporting documents were given 48 hours to collate these.

"Our community do not perceive prevention maximally. Not maximal. If we said that our community midwives have not informed them about this, it is not the case. They (midwives) has talk about "10T", the counseling, about the cost, where to go etc. But if we inform them prior to actual events, the community do not get it. Therefore, in the MoU there is a clause stating that the coverage needs a complete administration within $2 \times 24$ hours of working days... Yes, $2 \times 24$ hours working days. If it is a Sunday, it is not counted, because it is not working day. Like that, since it will be difficult to get a letter from the village office on non-working days,"(Dikes.01)

\section{Reinforcing factors}

The first driving factor related to Jampersal is support from community leaders, especially village officials. Greater support from the head of the village in the use of Jampersal can be facilitated by coordination with village midwifes regarding the availability of Jampersal budget, the existence of health budget in the village mid-term development plan (Rencana Pembangunan Jangka Menengah Desa/RPJMDes) for the introduction of health programs, and involvement of cadres and village family welfare women's groups $(P K K)$ to educate pregnant women about Jampersal. Other support is from head of village's wife to use Jampersal if they 
haven't owned JKN KIS card.

"...... from the wife of the village head (information on Jampersal)...yes like that, who are pregnant and close to due date, inform if she do not use KIS, use Jampersal. That's the information....yes, the letter is from village head, the impoverished letter from village office"(J.Salin.01)

In the villages where Jampersal utilization remains low, the village head acknowledged the reluctance of the community to prepare the administration, especially population administration related to a declaration of impoverished status. This is due to the busyness of the husband in working, a lack of interest to prepare requirements and wanting faster service. One of the constraints that often occur when preparing administrative requirements is the difference on the name written on the Family Card $(K K)$ with the name on the National Identity Card $(K T P)$. Other required documents cover type of education, marital status, employment status etc. These are relevant when village head decide whether to issue a declaration of impoverished status letter or not.

\section{DISCUSSION}

The results showed that good understanding of the Jampersal program was a crucial factor in the decision to use this program. Poor understanding coupled with poor perceptions of program administration requirements and processes make it difficult for husbands or families to use Jampersal. Poor facilitation by health care providers combined with the reluctance of village officials to assist in the administration process, further impacts upon low uptake.

The importance of awareness on the program was also raised by Fitriyanti in her research on high uptake of Jampersal (68\%) wherein respondents in the group had high level of awareness. ${ }^{9}$ It was also noted that the earlier the mother was informed about the program, the better ${ }^{10}$, since earlier contact and frequency of antenatal care are related to mothers' knowledge. Information about the Jampersal Program particularly birthing assurance coverage should be disseminated to pregnant women when they enter the third quarter of pregnancy so they have more time to prepare the eligibility requirements. They should be informed about the objectives and benefits of Jampersal and the requirements that should be prepared by pregnant women, husbands and families.

In connection with the explanation above, the role of health service providers is critical. In the guidelines for the Planning for Birth and Complications Prevention Program $(P 4 K)$, it is stated that the role of midwives during pregnancy is to provide counseling to pregnant women and families on child birth planning, namely birth assistance plans, delivery centers, preparing transportation, transportation costs and prospective blood donor candidates. ${ }^{11}$ Furthermore, in a study conducted in the working area of North Denpasar I $\mathrm{PHC}$ on the role of the head of family in determining the decision to switch from membership in local (provincial) health insurance to national health insurance for family members, there is concern for service quality, comprehensive benefits and sustainability of local health insurance (Jaminan Kesehatan Bali Mandara/JKBM).12 To improve utilisation of operational health funds $(B O K)$ at every level especially PHC, it should be used to support promotion of the benefit of Jampersal Program to the public. ${ }^{6}$

Family support is another important factor in the utilization of the Jampersal Program, especially from the husband. Husband support included preparing administrative requirements for Jampersal, such as preparing a Family Card and a declaration of impoverished status letter from the village head. The Jampersal requirements, even though they appear to be simple (KTP and Declaration of Impoverished Status), can be deterrent because they do not understand the process and some of them are totally unaware about the program. As the process is considered complicated and costly, some families decided to not utilize Jampersal instead opt to closest traditional birth attendance. ${ }^{13}$ Furthermore, the decision of the head of the family is also influenced by concern about the quality of service, the overall benefits and the sustainability of the financing system. ${ }^{14}$ This is strongly influenced by social culture and habits of the community, where decision making in the family is determined by the husband, parents/in-laws. ${ }^{15}$

Other support comes from outside of the family, namely community leaders, especially village officials and the village head. The village head is in charge of supporting the implementation of Jampersal program in his working area, including conducting promotion to the community, coordinating with the Village Midwifery Network and PHC, and facilitating Jampersal administrative requirements. The results of a study on the use of Jampersal in the Banten Province among Baduy tribe stated that the Baduy traditional leaders supported the use of Jampersal Program but the community must still adhere to the prevailing cultural mores. ${ }^{16}$

Lastly, this study found that the Jampersal Program in Bangli District was supported by a Decree of Bangli Regent which regulates the provisions contained in the Jampersal Technical 
Guidelines which include administrative provisions, however, the programs yet to incorporate independent midwives services. This fact impedes overall implementation due to differing community preferences regarding the delivery place. In some places, private midwife served as an alternative service which is closest and easier for the community in need of service. MCH services by private midwife include service before pregnancy, antenatal service, delivery, post-delivery service and between pregnancies services. ${ }^{17}$

\section{CONCLUSION}

Poor uptake of the Jampersal program in the Bangli District is related to the lack of optimal program introduction/promotion which results in the low understanding among some segments of the population who are eligible, and the emergence of poor perceptions regarding administration processes and the Jampersal services. The decision making mechanism in the family and the support of community leaders are the other key factors influencing uptake. Increased efforts by the Bangli District Health Office are needed to continue promotion of the Jampersal Technical Guidelines to health workers and the community, as well as expanding the Jampersal MoU network to include independent midwives. Coordination with the private midwife network is needed to improve service standards, align with the required quality standards of government health facilities.

\section{ACKNOWLEDGMENTS}

The authors thank the informants who participated in this study for their kind contribution to the study.

\section{AUTHOR CONTRIBUTION}

AKD designed the study, gathered and analysed the data, prepared and edited the manuscript. PJ was critically reviewed the development of the study, provided feedback and edited the manuscript, YK involved in the study design and provided feedback on the manuscript.

\section{CONFLICT OF INTEREST}

All authors declare no conflict of interest

\section{FUNDING}

The study was self-funded by the authors.

\section{REFERENCES}

1. Ministry of Health of The Republic of Indonesia. Rencana Aksi Kegiatan Direktorat Kesehatan Keluarga Tahun
2016-2019 [Activities Action Plan of the Family Health Directorate]. Jakarta; 2016.

2. Ministry of Health of The Republic of Indonesia. Petunjuk Teknis Penggunaan Dana Alokasi Khusus Nonfisik Bidang Kesehatan Tahun Anggaran 2017 [Technical Guidelines on the Use of Non Physical Special Allocated Fund for Health Year 2017]. 2017:8-109.

3. Ministry of Health of The Republic of Indonesia. Frequently asked questions: DAK Non Fisik Jaminan Persalinan Tahun Anggaran 2018 [Frequently asked questions on non physical special allocated fund for Jampersal]. Jakarta; 2018.

4. Bali Provincial Health Office. Laporan Realisasi Penggunaan DAK Non Fisik Bidang Kesehatan - Jampersal Triwulan IV Tahun 2017 [Report on the use of non physical special allocated fund for health - Jampersal the $4^{\text {th }} 3$ months Year 2017]. Denpasar; 2017.

5. Mandasari E. Analisis perbandingan pelaksanaan Jaminan Persalinan (Jampersal) pada Bidan Praktek Swasta (BPS) di wilayah Puskesmas Kota Semarang dengan Petunjuk Teknis (Juknis) Jampersal Tahun 2012 [Analysis of Jampersal implementation comparation between the private midwives in the working area of Puskesmas Kota Semarang and the technical guidelines of Jampersal Year 2012]. Jurnal Kesehatan Masyarakat Universitas Diponegoro. 2013;2(1).

6. Poole DL, Carlton TO. Model for analizing utilization of maternal and child health services. Health Soc Work. 1986;11(3):209-222.

7. Green LW, Kreuter MW. CDC's planned approach to community health as an application of PRECEED and an inspiration for PROCEED. J Heal Educ. 1992;23(3).

8. Braun V, Clarke V. Using thematic analysis in Psychology. Qualitative Research in Psychology. 2006;3(2).

9. Fitryanti. Pemanfaatan Program Jaminan Persalinan berdasarkan karakteristik ibu di Puskesmas Pauh Kambar Kecamatan Nan Subarais Kabupaten Padang Pariaman Tahun 2012 (Skripsi) [Utilization of Jampersal Program based on mother's characteristic at Puskesmas Pauh Kambar, Nan Sabaris Sub-district, Padang Pariaman District, 2012 (Undergraduate Thesis)]. Universitas Indonesia; 2012.

10. Hendrayani MD, Sawitri AAS, Karmaya INM. Perilaku pemeriksaan antenatal sebagai faktor risiko anemia gizi ibu hamil di Puskesmas II Denpasar Selatan tahun 2012 [Antenatal care behavior as a risk factor of nutritional anemia among pregnant women at South Denpasar II Public Health Centre, 2012]. Public Health and Preventive Medicine Archive. 2013;1(1):74-78.

11. Ministry of Health of The Republic of Indonesia. Pedoman Program Perencanaan dan Pencegahan Komplikasi (P4K) dengan stiker [Guidelines on The Complication Planning and Prevention Program (P4K) using stickers]. Jakarta; 2009.

12. Pemayun CIM, Januraga PP, Sudewi NMASR. Faktor predisposisi kepala keluarga dengan KTP Bali untuk mengikuti Program JKN Mandiri Kelas III: Studi kualitatif di wilayah kerja Puskesmas I Denpasar Utara [Predisposing factors of the head of family with Bali ID Card to join the National Health Insurance (JKN) Program: A qualitative study in Health Centre I North Denpasar]. Public Health and Preventive Medicine Archive. 2016;4(1):48-53.

13. Handayani L, Suharmiati, Kurniawan A, Nuraini S, Rahanto S, Wasito B, et al. Pemanfaatan Jaminan Persalinan untuk pelayanan kesehatan ibu dan anak di 12 kabupaten/kota: Mengeliminasi kendala sosial budaya dalam persalinan aman [Utilization of service delivery insurance (Jampersal) for maternal and child health services in 12 districts/cities: Eliminate the socio-cultural obstacle on safe delivery]. Buletin Penelitian Sistem Kesehatan. 2013;16(4):419-427. 
14. Panai R. Hambatan pemanfaatan Jaminan Persalinan (Jampersal) di Puskesmas Wilayah Kabupaten Bone Bolango Provinsi Gorontalo (Tesis) [Barriers of Jampersal utilization at Puskesmas in Bone Balango District, Gorontalo Province (Thesis)]. Universitas Gadjah Mada; 2014.

15. Puspita E. Pemanfaatan Jaminan Persalinan (Jampersal) [Jampersal utilization]. Jurnal Health Quality. 2011;3(2):69140.

16. Nuraeny L, Hadi EN. Kajian pemanfaatan Program Jampersal di Wilayah Baduy Puskesmas Cisimeut Kabupaten Lebak Provinsi Banten Tahun 2013 (Skripsi)
[Study on the utilization of Jampersal Program at The Baduy Area, Puskesmas Cisimeut, Labak District, Banten Province Year 2013 (Undergraduate Thesis)]. Universitas Indonesia; 2013.

17. Ministry of Health of The Republic of Indonesia. Ijin dan penyelenggaraan praktik bidan [Midwives practice and permit]. Jakarta; 2017.

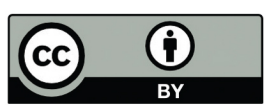

This work is licensed under a Creative Commons Attribution 